Mеталлофиз. новейшие технол. / Metallofiz. Noveishie Tekhnol. (C) 2016 ИМФ (Институт металлофизики 2016 , т. 38, № 6, сc. 737-750 / DOI: 10.15407/mfint.38.06.0737 им. Г. В. Курдюмова НАН Украины) Оттиски доступны непосредственно от издателя

Фотокопирование разрешено только

Напечатано в Украине.

в соответствии с лицензией

PACSnumbers: 61.50.Lt, 61.72.Dd, 64.75.Nx, 71.15.Mb, 71.15.Nc, 81.30.Mh, 82.60.Lf

\title{
Precipitation Reactions in Nickel-Hydrogen System: ab initio Study
}

\section{S. M. Teus}

G.V.Kurdyumov Institute for Metal Physics, N.A.S. of Ukraine, 36 Academician Vernadsky Blvd., UA-03680 Kyiv, Ukraine

A type of precipitation reactions in the nickel-hydrogen system is studied by means of first-principle atomic calculations. The concentration dependence of solution enthalpy is calculated, and its second derivative is shown to be negative within the hydrogen-to-nickel ratios, $\mathrm{H} / \mathrm{Ni}$, of $0.03-0.75$. This result suggests that a spinodal decomposition of the solid solution occurs resulting in formation of the hydrogen-rich and hydrogen-depleted phases. The obtained hydrogen concentrations in these conjugated phases are in consistency with the available experimental data. The effects of hydrogen concentration on the electronic structure and its correlation with thermodynamic stability of phases confirm that spinodal decomposition in the nickelhydrogen system has the electronic origin. The obtained results are at variance with the widely accepted concept of the nickel hydride.

Key words: spinodal decomposition, nickel-hydrogen system, hydride, $a b$ initio calculations.

Тип реакцій виділення в системі нікель-водень досліджено за допомогою розрахунків із перших принципів. Розраховано концентраційну залежність ентальпії розчинення, а також показано, що іiі друга похідна $\epsilon$ від'ємною в діяпазоні відношень водень-метал, $\mathrm{H} / \mathrm{Ni}$, від 0,03 до 0,75. Це означає, що має місце спинодальний розпад твердого розчину із формуванням збагаченої та збідненої воднем фаз. Одержані значення концентрацій водню в цих спряжених фазах узгоджуються з експериментальними даними. Вплив концентрації водню на електронну структуру, а також кореляція з термодинамічною стабільністю фаз підтверджують, що спи-

Corresponding author: Sergiy Myronovich Teus

E-mail: teus@imp.kiev.ua

Please cite this article as: S. M. Teus, Precipitation Reactions in Nickel-Hydrogen System: ab initio Study, Metallofiz. Noveishie Tekhnol., 38, No. 6: 737-750 (2016) (in English), DOI: 10.15407/mfint.38.06.0737. 
нодальний розпад у системі нікель-водень має електронну природу. Одержані результати знаходяться у протиріччі з широко розповсюдженою концепцією гідриду ніклю.

Ключові слова: спинодальний розпад, система нікель-водень, гідрид, розрахунки із перших принципів.

Тип реакций выделения в системе никель-водород изучен при помощи расчётов из первых принципов. Рассчитана концентрационная зависимость энтальпии растворения, а также показано, что её вторая производная является отрицательной в диапазоне отношений водород-металл, $\mathrm{H} / \mathrm{Ni}$, от 0,03 до 0,75. Это свидетельствует о том, что имеет место спинодальный распад твёрдого раствора с формированием обогащённой и обеднённой водородом фаз. Полученные значения концентраций водорода в этих сопряжённых фазах находятся в согласии с экспериментальными данными. Влияние концентрации водорода на электронную структуру и корреляция с термодинамической стабильностью фаз подтверждают, что спинодальный распад в системе никель-водород имеет электронную природу. Полученные результаты находятся в противоречии с широко распространённой концепцией гидрида никеля.

Ключевые слова: спинодальный распад, система никель-водород, гидрид, расчёты из первых принципов.

(Received March 23, 2016)

\section{INTRODUCTION}

Metal hydrides belong to a special class of chemical compounds that are formed due to reactions of hydrogen with metal atoms. Such interaction leads to significant changes in mechanical, electrical, magnetic and many other properties, which substantially extends the possibilities for practical applications. In the most straightforward way, the hydrides are used as hydrogen storage materials, as well as energy sources, sensors, actuators etc. In this relation, transition elements attract a special attention because of their unique properties arising from the partially filled $d$-electronic band.

Being transition element and because of similarities between the general view of the $\mathrm{Ni}-\mathrm{H}$ and $\mathrm{Pd}-\mathrm{H}$ phase diagrams (where the miscibility gap area is present), nickel became an object of particularly intensive researches $(e . g .,[1-14])$. A conclusion about the formation of nickel hydride was derived based on the non-diffusive character of hydrogen desorption kinetics [1-3]. It should be mentioned that, in $[4,5]$, the decomposition of nickel hydride was studied using X-ray diffraction (XRD) technique and it was shown that the decomposition follows a first order kinetics, whereas, in [6], the opposite result has been obtained. A non-linear behaviour of desorption rate was explained based on the effect of microstructure on the phase transition mechanism. 
Measurements of hydrogen penetration in nickel have been carried out using the electrochemical technique [7]. It was obtained that three different regions can be distinguished in the potential-composition curves. These regions correspond to a so-called $\alpha$-phase with the maximum hydrogen-to-metal, $\mathrm{H} / \mathrm{M}$, ratio of about $0.03, \beta$-phase with $\mathrm{H} / \mathrm{M}$ of about 0.6 and the region of two-phase mixture. With the same technique, it was found in [8] that the hydrogen content in nickel changes discontinuously from the composition of $\alpha$-phase to that of $\beta$-phase. Despite the evidence of existing miscibility gap, these results are interpreted as formation of a nickel hydride.

The hydride concept was also used to explain the observed dependence of electrical resistance on the hydrogen pressure [15]. At small hydrogen concentrations, the electrical resistance rose a few percent above the initial value; however, after the hydride phase start to precipitate, the resistivity significantly decreased that was attributed to the reduction in the scattering events.

The high-pressure hydrogen charging allows the thermodynamic study of nickel-hydrogen system with construction of the $T-P$ and $T-$ $C$ phase diagrams for hydride formation and its decomposition (e.g., $[12,13])$. A common result is that, with increasing temperature, the concentration range of the two-phase coexistence decreases, which is a sign of a crown, i.e. miscibility gap, not a chemical compound.

The analysis of available experimental data allows to formulate two important contradictions between the obtained results and their interpretation: (i) the claimed nickel hydride exists in a wide range of hydrogen concentration that can even exceed $\mathrm{H} / \mathrm{M}=1.0$ (e.g., [12]); (ii) this nickel hydride has the same f.c.c. crystal structure as the parent nickel and differs only by the increased lattice parameter of about $6 \%$, as it follows from the X-ray diffraction measurements (e.g., [14]). Both these features are not consistent with the common concept of chemical compounds, which exist in a narrow concentration range around their stoichiometric ratio and have the crystal lattice different from the matrix phase, e.g., the $\mathrm{Ti}-\mathrm{H}$ hydride [16].

The aim of this paper is to analyse the peculiarities of the nickelhydrogen system based on the first-principle atomic calculations with a similar approach as in [17] and, in thermodynamic terms, come to a conclusion about the type of the precipitation reaction that takes place in the course of hydrogen dissolution in nickel.

\section{METHODS OF CALCULATIONS}

First-principle atomic calculations of nickel containing the varying hydrogen concentration were performed within the framework of Density Functional Theory (DFT) $[18,19]$ using the Wien2k program package [20]. According to this theory, the total energy of a system 
could be presented as follows:

$$
E_{\text {tot }}=E_{\text {kin }}+E_{\text {ee }}+E_{\text {ne }}+E_{\text {xc }}+E_{\text {nn }},
$$

where $E_{\text {kin }}$ is a kinetic energy of non-interacting particles, $E_{\text {ee }}$ is electron-electron repulsion energy, $E_{\text {ne }}$ is nuclear-electron attraction energy, $E_{\mathrm{xc}}$ is exchange-correlation term, and $E_{\mathrm{nn}}$ is a Coulomb repulsive energy of fixed nuclei.

The first four terms in equation (1) are the functions of spin densities. To obtain the value of the total energy, the Kohn-Sham equations have to be constructed and solved using a self-consistent iterative process. For the accurate description of the exchange and correlation effects, the Generalized Gradient Approximation (GGA) [21] was used.

The convergence tests were performed to find the optional values of the number of wave functions in the basis set and the number of $\mathbf{k}$ points, which are used for the Brillouin zone sampling according to the Monkhorst-Pack scheme [22]. It should be also mentioned that the wave functions in the unit cell are of two types. For the region inside atomic spheres, the spherical wave functions are used and, for the interstitial region, the basis consists of the plane waves. Such approach gives the necessary flexibility for the basis set, which results in a quicker convergence during the calculations in comparison with the single-type basis and in the better description of the core states.

For calculations, the unit cell was used that consists of 32 nickel atoms with variable quantity of hydrogen atoms to cover a wide range of hydrogen concentrations. In all cases, the spin polarization effects were also included to take into account the magnetic contribution to the total energy. Brillouin zone integration is performed with a $15 \times 15 \times 15 \mathrm{k}$-point mesh. The muffin-tin radii of nickel and hydrogen atoms $\left(R_{\mathrm{mt}}(\mathrm{Ni})=2.08 \mathrm{Bohr}, R_{\mathrm{mt}}(\mathrm{H})=1.12 \mathrm{Bohr}\right)$ were keep constant within the calculation of different configurations for proper comparison. The magnitude of the largest vector $\mathbf{G}$ in the Fourier expansion is equal 20. The force convergence was set to $0.1 \mathrm{mRy} / \mathrm{a} . \mathrm{u}$. with the interatomic forces between the atoms less than $2 \mathrm{mRy} / \mathrm{a} . \mathrm{u}$. for accurate determination of atomic positions. To find the equilibrium lattice constant, the Murnaghan's equation of state [23] was used by fitting the total energy versus the unit cell volume.

To determine the solution enthalpy of hydrogen atoms in the nickel lattice, the following equation was used:

$$
\Delta H_{\mathrm{s}}=E_{\mathrm{tot}}\left(\mathrm{NiH}_{n}\right)-E_{\mathrm{tot}}(\mathrm{Ni})-(n / 2) E_{\mathrm{H}_{2}},
$$

where $E_{\text {tot }}(X)$ are total energies of corresponding cells after all types of relaxation (volume, shape, atomic positions) and $E_{\mathrm{H}_{2}}$ is a total energy of the hydrogen molecule, which is calculated by putting two hydrogen 
atoms in a cubic box with quite large length (20 Bohr) to exclude any possible interactions that can arise because of periodic boundary conditions. Such calculation results in a bond length distance of 0.751 angstroms, binding energy of $4.70 \mathrm{eV}$ and vibrational frequency of 4270 $\mathrm{cm}^{-1}$, which are in a good agreement with available experimental values of $0.741 \AA, 4.75 \mathrm{eV}$ and $4395 \mathrm{~cm}^{-1}$ [24].

The phonon effect and thermodynamic functions were calculated using Phonon software [25, 26] within the harmonic approximation. To include the effects concerned with phonons, the dynamical matrix has to be constructed. The elements of such matrix are the force constants that could be obtained from the $a b$ initio calculations according to a direct method [27, 28] and its modification [26]. Afterwards, by constructing the phonon density of state dependences, the thermodynamic functions could be determined. Using such approach, the zeropoint energy corrections to the systems with hydrogen atoms could be taken into account. In a simplest approximation, the force constants concerned with the displacements of nickel atoms from their equilibrium positions could be equal to zero as the mass of the nickel atom is significantly higher than that of the hydrogen atom. After the diagonalization of the Hessian matrix, the normal mode frequencies of hydrogen atoms could be determined and the zero-point energy could be calculated by summing up the zero-point vibrational energies: $E_{\text {zpe }}=$ $=(1 / 2) \Sigma\left(h v_{i}\right)$, where $v_{i}$ is a real normal mode frequency.

\section{RESULTS}

The comparison of possible interstitial sites for hydrogen dissolution in nickel in terms of energy reveals that hydrogen atoms prefer to occupy the octahedral interstitial positions in the f.c.c. lattice within all the range of hydrogen concentrations studied. This result is in consistency with a huge array of experimental data obtained by means of X-ray diffraction measurements (e.g., $[29,30])$.

Figure 1 demonstrates the total cohesive energy of the calculated $\mathrm{Ni}-\mathrm{H}$ structure as a function of hydrogen concentration. The total cohesive energy was defined as a difference between the calculated total energy per cell and the sum of the total energies of free atoms included in the cell, $E_{\text {coh }}=E_{\text {tot }}-\Sigma_{E_{\text {totat at }}}$, where summation is performed over all atoms in the cell. Thus, the total cohesive energy characterizes the energy of all bonds in the studied atomic ensembles and corresponds to the thermodynamic stability of a system. As follows from this Figure, the total cohesive energy monotonically decreases with increasing hydrogen concentration in the nickel lattice, which is due to formation of new bonds between the hydrogen and host atoms.

The calculated enthalpy of hydrogen dissolution in the nickel lattice that includes the zero-point energy correction is presented in Fig. 2, $a$. 


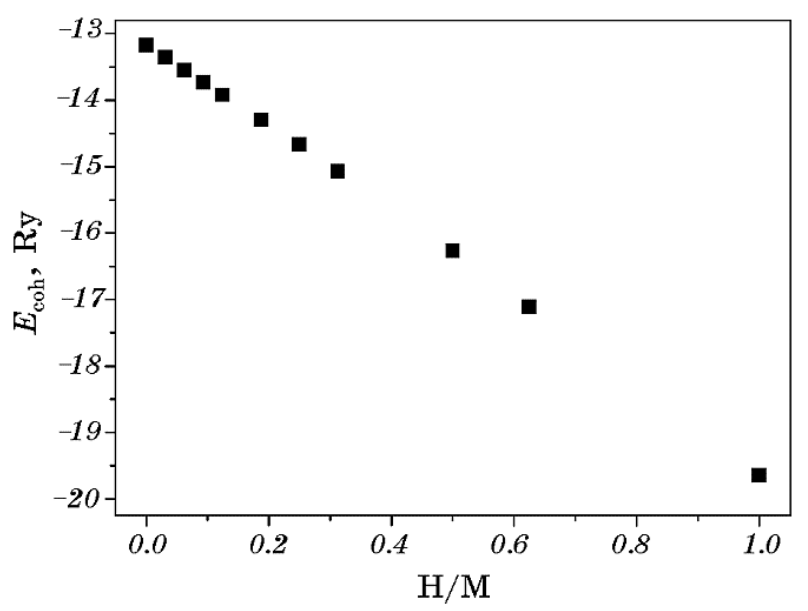

Fig. 1. Total cohesive energy as a function of hydrogen concentration in $\mathrm{Ni}-\mathrm{H}$ system.

As follows from its concentration dependence, at the beginning the solution enthalpy increases with the increase of the $\mathrm{H} / \mathrm{M}$ ratio up to 0.25 and then decreases with further increasing hydrogen concentration. The second derivative of the solution enthalpy is presented in Fig. 2, $b$. As seen, it has a negative sign in the concentration range from 0.03 to 0.75 .

According to the obtained results, the solution enthalpy of one hydrogen atom in the nickel lattice amounts to $0.14 \mathrm{eV}$, which corresponds to the available experimental data [31-33]. Nevertheless, some remarks should be given here. Usually, measurements of the solution enthalpy take place at elevated temperatures and a correct extrapolation of experimental data to the low temperature range should be performed to allow a direct comparison with the data obtained by means of ab initio calculations. In Ref. [34], the analysis of a large array of experimental data has been carried out and it was shown that the heat of solution of hydrogen in nickel depends on the experimental temperature range and tends to increase with increasing temperature.

Figures $3, a, b$ show the total density of states (DOS) for the spin up and spin down electron states in the $\mathrm{NiH}_{x}$ system in comparison with that in the pure nickel. A detailed behaviour of the DOS in the vicinity of the Fermi level is shown in the insert to each Figure. In case of pure nickel for the spin-up channel, the bonding and antibonding states are almost completely filled, whereas for the spin-down channel, the antibonding states are only partially filled. The interaction between nickel and hydrogen atoms causes the appearance of bonding states at the bottom of the metallic $d$-band. The analysis of partial contributions to the total DOS from the electrons of different atoms and different 

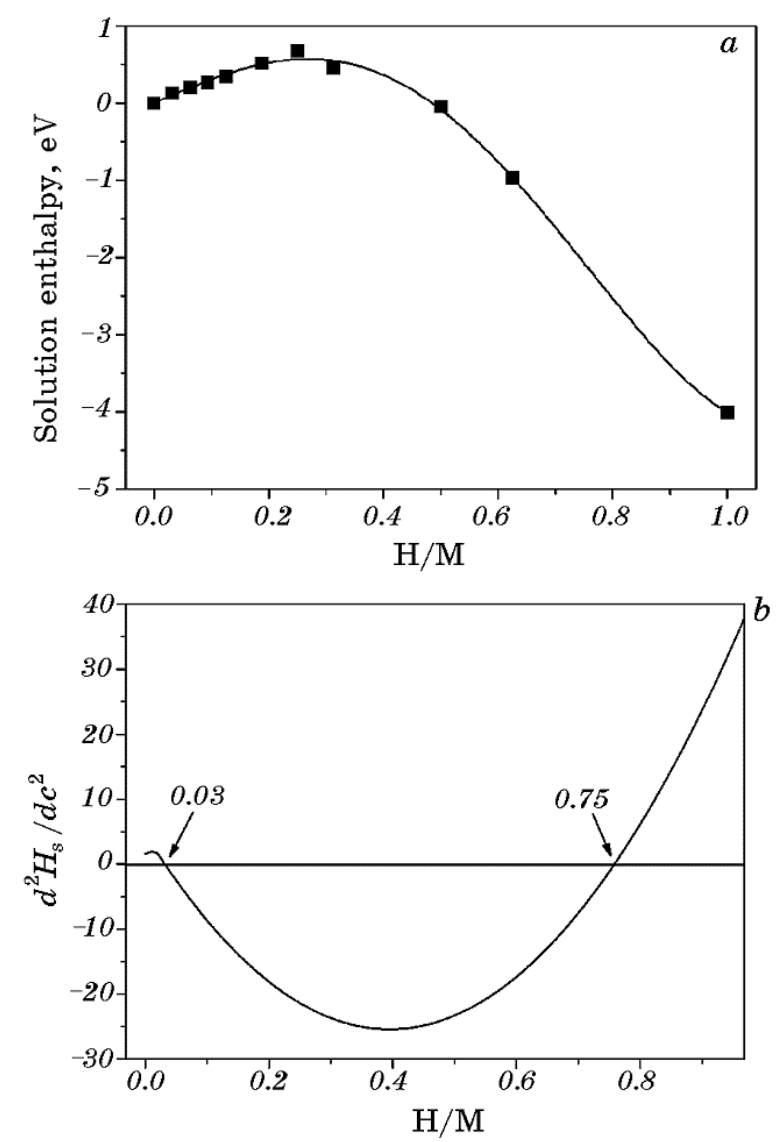

Fig. 2. Variation in the hydrogen solution enthalpy for $\mathrm{Ni}-\mathrm{H}$ system with increasing hydrogen content $(a)$. Second derivative of the solution enthalpy as a function of hydrogen content $(b)$.

symmetries reveals that the $\mathrm{Ni} 4 s$ and $\mathrm{H} 1 s$ electrons are fully overlapping and form the $\mathrm{Ni}-\mathrm{H}$ bonds. Because of degeneration, the $3 d$ orbital is split into $e_{g}$ and $t_{2 g}$ groups, which are different in their symmetry. According to the obtained results, the $3 d e_{g}$ electrons also contribute to the $\mathrm{Ni}-\mathrm{H}$ bonds, whereas the $3 d t_{2 g}$ electrons do not take part in the Ni$\mathrm{H}$ interaction.

The dissolution of hydrogen atoms in the nickel crystal lattice has a significant effect on the electronic structure, changing, thereby, the DOS at the Fermi level. For the majority spin channel, an increase in hydrogen concentration results in the increase of the DOS at the Fermi level, whereas, for the minority spin channel, the behaviour is nonmonotonous: up to the $\mathrm{H} / \mathrm{M}$ ratio of about 0.27 , the DOS at the Fermi level increases, however, above this concentration, the DOS at the 

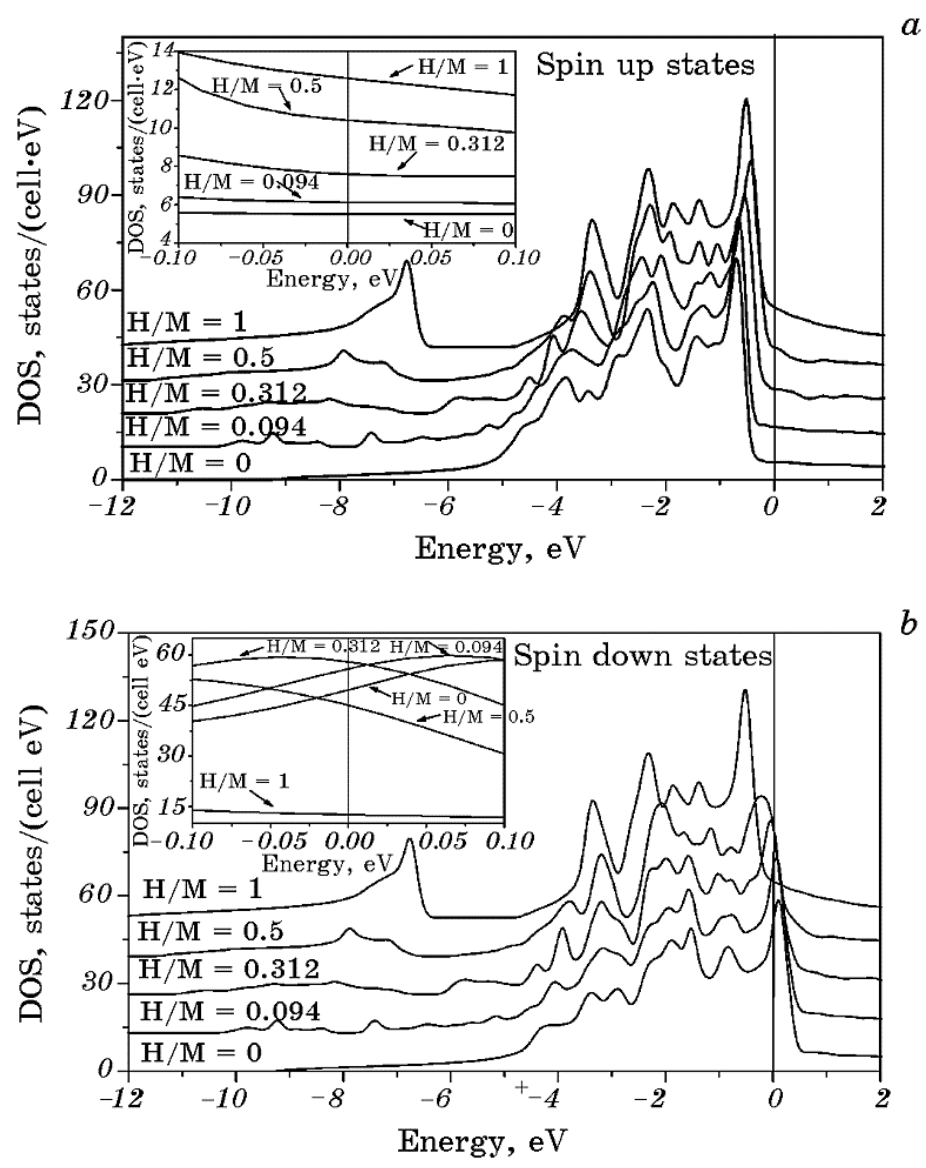

Fig. 3. Concentration dependence of density of states for spin up $(a)$ and spin down $(b)$ electron states in the $\mathrm{Ni}-\mathrm{H}$ system in comparison with that in the pure Ni.

Fermi level decreases. Corresponding concentration dependences of spin up and spin down electron states and their total values are presented in Fig. 4. A substantial decrease in the DOS at the Fermi level caused by the filling of antibonding states explains the magnetic behaviour of $\mathrm{Ni}-\mathrm{H}$ system, which becomes paramagnetic at high hydrogen contents in consistency with the experimental data [11].

The temperature dependence of the Helmholtz free energy of $\mathrm{Ni}-\mathrm{H}$ system is shown in Fig. 5 for different $\mathrm{H} / \mathrm{M}$ ratios. The phonon contribution was calculated within the framework of the harmonic approximation. As seen, with increasing hydrogen content, the phonon contribution does not change the general behaviour of free energy within the studied temperature range. 


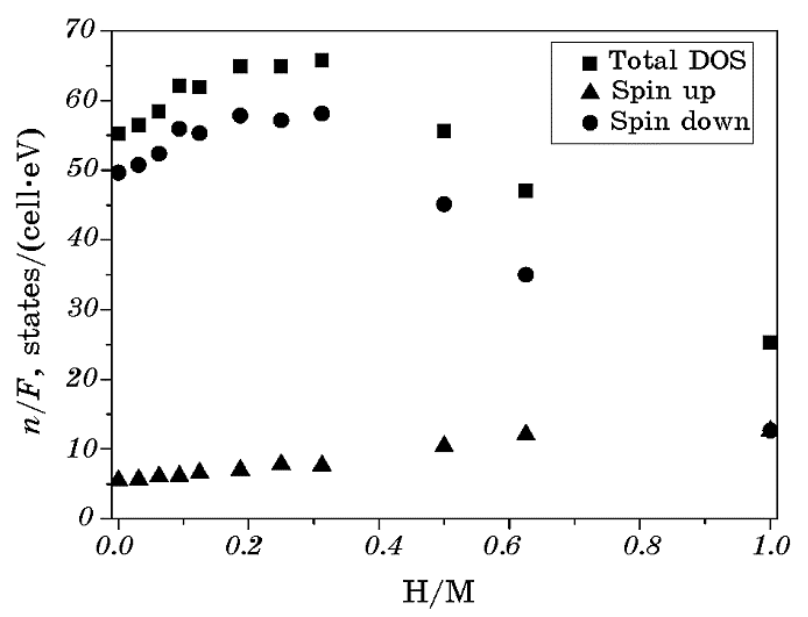

Fig. 4. Density of states at the Fermi level as a function of hydrogen concentration for different spin orientations.

\section{DISCUSSION}

Hydrogen effect on the energy characteristics, and electronic structure in nickel is studied to analyse the type of precipitation reactions in terms of thermodynamics.

According to classical theory of solid solutions, two types of precipitation reactions are possible [35]. In the first type, the Gibbs energy of a supersaturated solid solution cannot be spontaneously reduced to its minimum at given temperature because the curvature of the energycomposition curve is always positive. In this case, the Gibbs energy can be decreased only if a new distinctly different phase with lower energy is nucleated. This type of precipitation reaction is characterized by some energy barrier, which should be overcome to initiate the nucleation process. In the second type of precipitation reactions, the Gibbs energy is characterized by a single curve with a definite maximum and two local minima. The precipitation phases belonging to this single curve should have the same type of the crystal lattice. As a result, below some critical temperature, the oversaturated solid solution is decomposed into two phases of fixed compositions. A mechanism of such reaction is the spinodal decomposition that takes place in a concentration range limited by the area of the negative sign in the curvature of the energy-composition diagram.

As follows from the concentration dependence of the total cohesive energy presented in Fig. 1, with increasing hydrogen concentration in nickel, the cohesive energy monotonically decreases. The absence of any deviations from its linear behaviour suggests that the precipitation reaction proceeds without energy barriers, which is one of fea- 


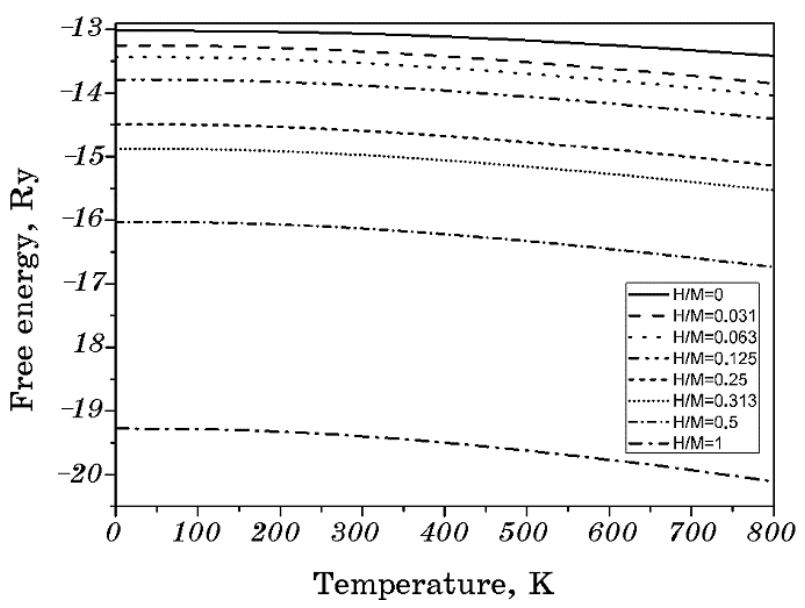

Fig. 5. Temperature dependence of the Helmholtz free energy for different hydrogen concentrations in $\mathrm{Ni}-\mathrm{H}$ system.

tures for spinodal mechanism of solid solution decompositions.

The absence of any energy barriers for the reaction and the identity of the crystal structure in 'nickel hydride' and parent nickel are the signs that the composition dependence of free energy should be described by a single curve for both phases. Moreover, an important thermodynamic parameter determining this type of precipitation reaction is the sign of the second derivative of the energy-composition curve. The result of such analysis is shown in Fig. 2, $b$. As seen, there is a certain $\mathrm{H} / \mathrm{M}$ range of 0.03 to 0.75 where the precipitation reaction occurs via spinodal decomposition. It suggests that, within this concentration range, the supersaturated solid solution is decomposed into the hydrogen-rich and hydrogen-depleted phases of fixed compositions.

The obtained results can be compared with the available experimental data. Using XRD, the nickel hydride formation was studied in situ during cathodic hydrogen charging [36]. Some variation was found in the position of the $\beta-\mathrm{NiH}_{x}$, i.e. 'nickel hydride', reflections in the diffraction patterns. Possible reasons for such behaviour were analysed and a conclusion was made that it is due to the change in the stoichiometric coefficient $x$ of this phase $(x>0.7)$. After the cathodic polarization was switched off, the lattice parameter of $\beta-\mathrm{NiH}_{x}$ phase was gradually decreased to that corresponding to $x=0.7$ and then, with decreasing the volumetric hydrogen content, the change in the volume fraction of the $\beta-\mathrm{NiH}_{0.7}$ phase was observed. A similar result was recently obtained in [37]; see Fig. 6. A change in the X-ray diffraction pattern of the hydrogen-charged nickel was analysed in the course of hydrogen degassing. It was shown that, directly after charging, a sin- 


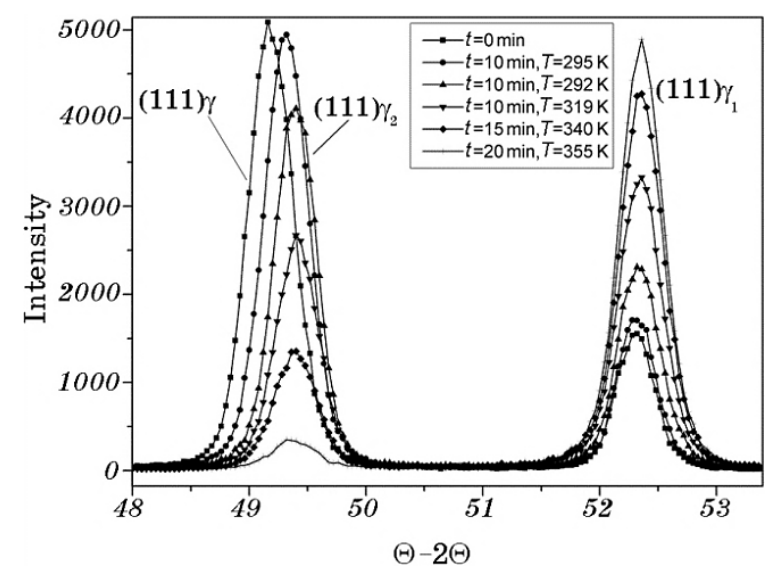

Fig. 6. X-ray diffraction for hydrogen-charged nickel [36]. Measurements at $118 \pm 5 \mathrm{~K}$ with subsequent holding at higher temperatures for a certain period of time.

gle (111) reflection is present corresponding to the $\mathrm{H} / \mathrm{M}$ ratio of 0.75 . Due to hydrogen degassing, this peak shifted to the position (111) $\gamma_{2}$ corresponding to $\mathrm{H} / \mathrm{M}=\mathbf{0 . 6 5}$ and an additional reflection (111) $\gamma_{1}$ appeared corresponding to the hydrogen content of $\mathrm{H} / \mathrm{M}=0.02$. In the course of subsequent stages of hydrogen degassing, the transfer of intensities from $\gamma_{2}$ to $\gamma_{1}$ occurred.

These results show that (i) the so-called 'nickel hydride' exists in a certain range of hydrogen concentration and has the same lattice as the parent nickel and (ii) during degassing, after reaching a certain $\mathrm{H} / \mathrm{M}$ value, the supersaturated solid solution decomposes into two phases of fixed hydrogen concentrations via spinodal mechanism. A comparison of hydrogen contents in both phases, $(\mathrm{H} / \mathrm{M}$ of hydrogen-rich phase is equal to 0.75 , whereas in hydrogen-depleted state $H / M$ is of about $0.03)$, confirms that our theoretical results are in consistency with the experimental data.

It is also interesting to compare the results of our calculations with the experiments carried out by Baranowski et al. [15], where the electrical resistance of nickel was measured as a function of gaseous hydrogen pressure. A significant change in the electrical resistivity was observed if the hydrogen pressure has exceeded $6 \mathrm{kbar}$, which was attributed by the authors to the formation of the hydride phase. Using the expression for hydrogen concentration derived in [38] and taking into account the hydrogen solution enthalpy obtained in our calculations, the $\mathrm{H} / \mathrm{M}$ ratio corresponding to the start of such sudden decrease in the electrical resistivity can be estimated:

$$
C_{\mathrm{H}}=\alpha \sqrt{F} \exp (-\Delta H /(R T)),
$$


where $\alpha$ is a constant, $F$ is a fugacity, $R$ is a gas constant, $\Delta H$ is an enthalpy for dissolution of hydrogen atom in a metal and $T$ is a temperature. The $\mathrm{H} / \mathrm{M}$ ratio of 0.07 is obtained from this estimation. This value falls into our calculated concentration range for the existence of two solid solutions resulted from spinodal decomposition and is close to its low limit.

It was shown earlier that the spinodal decomposition has an electronic origin [39, 43, 17], which suggests that a correlation should exist between the parameters that describe the electronic structure of a system and its inclination to spinodal decomposition. Within the rigidband approximation, the second derivative of the solution enthalpy is related with the DOS at the Fermi level by the following equation [3941]:

$$
\frac{d^{2} H_{s}}{d c^{2}} \propto \frac{1}{n(F)} .
$$

Taking into account that the rigid-band model fails to describe the spinodal decomposition, nevertheless, the inverse proportionality between solution enthalpy and DOS at Fermi level was confirmed to exist $[43,17]$. The comparison of the second derivative of the solution enthalpy, as shown in Fig. 2, $b$, with the concentration behaviour of DOS at the Fermi level, as presented in Fig. 4, also confirms the inverse proportionality between the components of Eq. (4) for the $\mathrm{Ni}-\mathrm{H}$ system.

The temperature dependence of the Helmholtz free energy for varying hydrogen concentration in nickel is shown in Fig. 5. As seen, the phonon contribution to the total energy does not lead to any deviation from stability of systems within the studied temperature range. This is an indication that the phonons are not responsible for the spinodal decomposition and confirms that this type of decomposition in the solid solutions is of the electronic nature.

\section{SUMMARY}

The study of the nickel-hydrogen system by means of ab initio atomic calculations was carried out. The total cohesive energy of the calculated structure monotonically decreases with increasing hydrogen concentration, which means that the precipitation reaction, that takes place in nickel-hydrogen system, occurs without any energy barrier. This result and the identity of the crystal lattices of the precipitated phases indicate that the free energy-concentration dependence of such two-phase system is described by a single curve. It was shown that the second derivative of the solution enthalpy has a negative sign within the range of the hydrogen concentrations of 0.03 to 0.75 . Such behav- 
iour means that, within this concentration range, the decomposition of solid solution occurs via spinodal mechanism. This result is consistent with the available experimental data.

The analysis of the hydrogen effect on the electronic structure of the $\mathrm{Ni}-\mathrm{H}$ system confirms the existing literature data about the correlation between the behaviour of second derivative of the solution enthalpy and the density of states at the Fermi level. The phonon contribution to the total energy was studied, and it was shown that such correction does not change the behaviour of energy curves. This is an additional confirmation that the spinodal decomposition in the $\mathrm{Ni}-\mathrm{H}$ system has an electronic origin.

\section{ACKNOWLEDGMENT}

The author would like to thank Prof. Valentin Gavriljuk for the helpful discussion and valuable comments during the article preparation.

\section{REFERENCES}

1. B. Baranowski, Z. Szklarska-Smialowska, and M. Smialowski, Bull.Acad. Pol. Sci., 6: 179 (1958).

2. B. Baranowski, Bull.Acad.Pol.Sci., 7: 907 (1959).

3. B. Baranowski, Bull.Acad. Pol. Sci., 7: 891 (1959).

4. A. Janko, Bull.Acad.Pol.Sci., 8: 131 (1960).

5. St. Rashkov, M. Monev, and I. Tomov, Surf. Technol., 16: 203 (1982).

6. I. Tomov, M. Monev, M. Mikhailov, and S. Rashkov, J.Appl. Electrochem., 22: 82 (1992).

7. B. Baranowski and Z. Szklarska-Smialowska, Electrochimica Acta, 9: 1497 (1964).

8. B. Baranowski, Bull.Akad.Pol.Sci., 7: 897 (1959).

9. A. Janko and P. Michel, Compt. Rend., 251: 1001 (1960).

10. H. Jarmolowicz and M. Smialowski, J. Catalysis, 1: 165 (1962).

11. H. J. Bauer and E. Schmidbauer, Z. Phys., 164: 367 (1961).

12. V. E. Antonov, J.Alloys Compd., 330-332: 110 (2002).

13. Y. Fukai, S. Yamatomo, S. Harada, and M. Kanazawa, J.Alloys. Compd., 372: L4 (2004).

14. A. Janko, Naturwissenschaften, 47: 225 (1960).

15. B. Baranowski and S. M. Filipek, J.Alloys. Compd., 404-406: 2 (2005).

16. A. Bourret, A. Lasalmonie, and S. Naka, Scr. Metal., 20: 861 (1986).

17. P. Olsson, I. A. Abrikosov, and J. Wallenius, Phys. Rev. B, 73: 104416 (2006).

18. P. Hohenberg and W. Kohn, Phys. Rev., 136: B864 (1964).

19. W. Kohn and L. J. Sham, Phys. Rev., 140: A1133 (1965).

20. P. Blaha, K. Schwarz, G. K. H. Madsen, D. Kvasnicka, and J. Luitz, WIEN2k, An Augmented Plane Wave + Local Orbitals Program for Calculating Crystal Properties (Wien, Austria: Techn. Universität Wien: 2001).

21. J. P. Perdew, S. Burke, and M. Ernzernhoff, Phys. Rev. Lett., 77: 3865 (1996).

22. H. J. Monkhorst and J. D. Pack, Phys. Rev. B, 13: 5188 (1976). 
23. F. D. Murnaghan, Proc. Natl.Acad.Sci., 30: 244 (1944).

24. K. P. Huber and G. Hertzberg, Molecular Spectra and Molecular Structure IV: Constants of Diatomic Molecules (New York: Van Norstrand Reinhold: 1979).

25. K. Parlinski, Software Phonon (Cracow: 2010).

26. K. Parlinski, Z. Q. Li, and Y. Kawazoe, Phys. Rev. Lett., 78: 4063 (1997).

27. K. Kunc and R. M. Martin, Phys. Rev. Lett., 48: 406 (1982).

28. M. T. Yin and M. L. Cohen, Phys. Rev. B, 26: 3259 (1982).

29. E. O. Wollan, J. W. Cable, and W. C. Koehler, J. Phys. Chem. Solids, 24: 1141 (1963).

30. J. W. Cable, E. O. Wollan, and W. C. Koehler, J. Phys., 25: 460 (1964).

31. C. Papastaikoudis, B. Lengeler, and W. Jager, J. Phys. F: Met. Phys., 13: 2257 (1983).

32. W. R. Robertson, Z. Metallkd., 64: 436 (1973).

33. K. Yamakawa and F. E. Fujita, Jpn. J.Appl. Phys., 16: 1747 (1977).

34. K. Zeng, T. Klassen, W. Oelerich, and R. Bormann, J.Alloys. Compd., 283: 151 (1999).

35. R. D. Doherty, Physical Metallurgy (Amsterdam: Elsevier Science BV: 1996), p. 1365 .

36. R. Juskenas, A. Selskis, and V. Kadziauskiene, Electrochim. Acta, 43: 1903 (1998).

37. D. N. Movchan, S. M. Teus, G. S. Mogilny, and V. G. Gavriljuk, Metallofiz. Noveishie Tekhnol., 35, No. 6: 821 (2013).

38. C. San Marchi, B. P. Somerday, and S. L. Robinson, Int. J. Hydrogen Energy, 32: 100 (2007).

39. B. Alling, A. Karimi, and I. A. Abrikosov, Surf. Coat. Technol., 203: 883 (2008).

40. H. Jones, J. Phys. Radium, 23: 637 (1962).

41. H. Jones, Proc. R. Soc. Lond. A, 144: 225 (1934).

42. P. A. Korzhavyi, E. A. Smirnova, I. E. Eibel'man, I. A. Abrikosov, A. V. Ruban, and Yu. Kh. Vekilov, Phys. Solid State, 39: 515 (1997).

43. E. A. Smirnova, P. A. Korzhavyi, Yu. Kh. Vekilov, B. Johansson, and I. A. Abrikosov, Phys. Rev. B, 64: 020101(R) (2001). 